\title{
ECONOMETRIC ANALYSIS OF EXCHANGE RATE IN SERBIA AND ITS INFLUENCE ON AGRICULTURAL SECTOR
}

\author{
Brankica Pažun ${ }^{1}$, Zlatko Langović2 ${ }^{2}$ Ana Langović Milićević
}

\begin{abstract}
Summary
This paper attempts to empirically estimate equilibrium exchange rate level of Serbian dinar. In that purpose reduced form equilibrium real exchange rate approach (ERER) is used, developed by IMF's Consultative Group on Exchange Rate Issues (CGER).

The research was made by using ARDL approach in the single-country analysis. It has been started from dynamic model which has described relation between real effective exchange rate and a set of fundamental variables. Bound test has been provided due to determination of the long-term relationship existence between variables. F-statistics has been used for long-term relationship testing between dependent variable and set of indicators. Since assumptions were met, least squares method was used for coefficient estimation. The results have shown constant dinar's overvaluation over medium term.
\end{abstract}

Key words: ARDL, assessment, equilibrium real exchange rate, ERER, Serbia

JEL: $C 33, F 31, F 41, O 24, Q 10$

\section{Introduction}

IMF's Consultative Group on Exchange Rate Issues (CGER) has been working on exchange rate estimations for 20 years, as it has always been a current issue, especially in recent decades, in period of globalization and trade and financial integration of the world economy. Their activities were first focused on advanced countries, and in the 21 st century have expanded on developing economies, as well.

CGER approach consists of three complementary methodologies: the method of

1 Brankica Pažun Ph.D., Assistant Professor, Alfa University, Faculty of Engineering Management, Vojvode Mišića Boulevard no. 43, 11000 Belgrade, Serbia, Phone: +381 1141 40 420, E-mail: bpazun@gmail.com

2 Zlatko Langović Ph.D., Associate Professor, John Naisbitt University, Faculty of Business Studies, Goce Delčeva Street no. 8, 11070 Belgrade, Serbia, Phone: +381 1122030 29, E-mail: zlmegatrend@gmail.com

3 Ana Langović-Milićević Ph.D., Full Professor, University of Kragujevac, Faculty of Hotel Management and Tourism, Vojvodjanska bb, 36210 Vrnjacka Banja, Serbia, Phone: + 38136515 0024, E-mail: ana.langovic@kg.ac.rs

EP 2016 (63) 1 (47-59) 
macroeconomic balance (MB), the method of external sustainability (ES) and the method of reduced equations of the equilibrium real exchange rate (ERER).

The prolonged and significant real exchange rate deviation from the equilibrium level (specifically, in terms of overvaluation can lead to a deterioration of the current account and trade balance, speculation, foreign debt increasing, investment decline, productivity and overall economic growth decreasing.(Pazun et al., 2014)

As the equilibrium exchange rate level cannot be directly monitored, there are different methodologies for assessing equilibrium exchange rate and, depending on model, these concepts often yield conflicting results (Bussiere et al., 2010). Particularly, there has been challenge in emerging countries and developing economies, such as Serbia, with structural problems, data unavailability, and high macroeconomic volatility. (Pazun et al., 2014)

Therefore, the aim of this paper is to empirically estimate equilibrium exchange rate level of Serbian dinar. For this purpose reduced form of equilibrium real exchange rate (ERER) approach is used. This empirical concept has root in the behavioral equilibrium exchange rate (BEER) concept introduced by Clark and MacDonald (1998). The BEER concept involves direct econometric estimation of the real effective exchange rate (REER) equation as a function of the set of fundamental determinants without referring to internal and/or external equilibrium of the economy.

This analysis first creates reduced relation between a dependent variable, which is real effective exchange rate, and a set of fundamental variables. Based on econometric estimation of coefficients, equilibrium exchange rate is calculated. The last step consists of calculation the difference between current real effective exchange rate and the estimated equilibrium level. Compare to similar studies by IMF and/or national central banks, this individual research will provide the latest empirical evidence in case of Serbia.

The results of this paper point to overvaluation of Serbian real exchange rate over medium term.

The paper is organized as follows: Section II provides an overview of the relevant literature and conducted research related to the subject. Section III describes data and model used in order to deliver, as in section IV presented, empirical results of the exchange rate assessment and discussion. Section V describes the state of agricultural sector in Serbia. We conclude with the main findings, limitations and possible further research.

\section{Literature review}

Studies which belong to post Bretton Woods period mostly focus on predicting real exchange rate oscillating in the medium and long term, as well as on searching and influence of fundamental variables that provide the equilibrium exchange rate assessment.

In the study of Driver and Westaway (2004) overview of 14 different concepts for assessing the equilibrium exchange rate has been provided, thereby suggesting that different approaches suit different time periods. 
Rajan and Siregar (2006) in their work provide an analytical overview of few models and explore two interrelated questions:

1. which fundamentals are used in estimating the equilibrium real exchange rate ERER? and

2. what are the main differences between models?

In Siregar's research (Siregar, 2011) comparative analysis of few concepts has been provided, both with their theoretical framework and empirical results.

Research corresponding to the specific exchange rate assessment methodology implementation in developing countries can be found in work of Hinkle and Montiel (1999). Particularly, Egert, Halpern and MacDonald (2006) have provided research on the equilibrium exchange rate in the countries of Central and Eastern Europe, SouthEastern Europe, as well as ex-Soviet Union, and final conclusion of their study is there was no precise assessment because of model uncertainty, as well as the fundamentals (Egert et al., 2006)

Lee et al. (2008) explains three complementary methodologies for equilibrium exchange rate assessment, developed by International Monetary Fund consultative group on exchange rate issues (IMF CGER). These are: the macroeconomic balance (MB) approach, the reduced-form equilibrium real exchange rate (ERER) approach and the external sustainability (ES) approach. For the first time, extended versions of these methodologies are studied, covering not only advanced countries, as in the past, but also emerging market countries. Dynamic ordinary least squares (DOLS) methodology was undertaken on sample of 48 countries over 1980-2004 (six countries were excluded due to lack of data).

More detailed description and model setup can be found in work of Ricci, Milesi-Ferretti, and Lee (2008), where DOLS methodology was applied on panel with fixed country effects.

Similarly, in work of Bussiere et al. (2010) the time dimension covers period 1980-2007 with balanced panel of 44 economies, in case of annual data (Bussiere et al., 2010). At the quarterly frequency, data constraints are much more serious and sample consists of 14 economies (excluding from the NFA fundamentals). Authors provide both panel and single-country estimations.

In another analysis, so-called single-country assessment of the equilibrium exchange rate, Bussière et al. (2010) used ARDL concept (Autoregressive Distributed Lag Approach), which has the advantage over traditional Johansen procedure and a error correction model, and that is not necessary to provide unit root tests for each variable, where the results can be unreliable in the case of a short series and structural breaks.

Further, few research papers follow work of Bussiere et al. (2010), Lee et al. (2008), as well as the case of Latvia (Ajevskis et al., 2012). In this study, quarterly data covering the period from the first quarter of 2001 to the fourth quarter of 2010, were used. In estimation of Armenia (Weber, Yang, 2011) there have been provided both country specific single 
country equation for the ERER approach and cointegrated panel estimation techniques proposed by Pesaran (2006).

Existing literature points that there is difficulty of evaluation exchange rate deviation especially in case of transition economies, which have not still passed through structural reforms and with high uncertainty and macroeconomic volatility, as well as short time series.

\section{Data description and the research model}

In order to evaluate the misalignment level of real exchange rate needed to shift country economy to its equilibrium state (more precisely, around equilibrium path), ERER concept was performed.

The ERER approach involves the following three steps (IMF, 2006 and Lee et al., 2008):

1. a reduced-form relationship between the real exchange rate and a set of fundamentals is estimated,

2. the equilibrium real exchange rate is calculated using the coefficients obtained from the econometric relationship,

3. and, in the third step, the range of the exchange rate adjustment, in which would be re-attained equilibrium level, is calculated directly as the difference between the actual real exchange rate and the equilibrium value identified (estimated) in the second step.

As Serbia is out-of-sample in IMF panel estimations, we use single-country (time series) estimation in this paper.

This study used data for the period from 2002 to 2014. The selection period is conditioned by the absence of some of the variables for the previous years, on the one hand, since the beginning of Serbia's transition period is linked to the year 2001 (or 19994), and, on the other hand, the relative methodology compliance for calculating variables values in the recent past. Furthermore, the weights are calculated due to countries, the leading trade partners which participate in over $60 \%$ of the total trade with Serbia. In this way values of most variables are obtained (variable relative to trading partners).

Numerous economic sources have tried to identify the variables that influence medium and long term equilibrium determination.

Following works of Lee et al. (2008), Bussière and associates (2010), as well as work of Weber and Yang (2011), next indicators are found in the model: net foreign assets (NFA), fiscal balance relative to trading partners $(\mathrm{fb})$, terms of trade $(\mathrm{tt})$, total government consumption relative to trading partners (gg), openness to trade (op), total investments relative to trading partners (tt), real per capita GDP (gdpO). Most of indicators is the natural logarithm.

The data used for model estimation come from various sources, which can be seen in the table A1 in Appendix.

4 According to IMF, transition period in Serbia starts in 1999 
The model used in this paper is dynamic model presenting real effective exchange rate in natural logarithm (lr) as dependent variable, and $\left\{x_{s, t}\right\}_{s=1}^{k}$ fundamental variable set, as followed:

\section{MODEL}

$$
\begin{aligned}
& \Delta l r_{t}=\alpha l r_{t-1}+\beta_{1} \Delta n f a+\beta_{2} \Delta f b+\beta_{3} \Delta l g d p o+\beta_{4} \Delta \operatorname{logop}+\beta_{5} n f a_{t-1}+ \\
& \beta_{6} f b_{t-1}+\beta_{7} l g d p o_{t-1}+c+\varepsilon_{t}
\end{aligned}
$$

\section{Empirical results and discussion}

In the case of this study, as the time series is short, and large number of parameters exist, the analysis was performed with several models, and each used a smaller number of indicators. Although the software automatically selects the optimal structure according to specified information criterion, and provides an estimate of the number of lags for the appropriate sample, given the small number of observations, only one delay specifically in this case could have been accepted.

In order to determine the existence of long-term relationships between the fundamentals, the bound test developed by Pesaran, Shin and Smith (2001) has been provided. F statistics is used in order to test long-term relations between the real effective exchange rate and its fundamentals. As long as the value of F-test is beyond these limits, it can be concluded that there is a long-term relationship between the independent variables and the dependent, without information on the integration degree of reggresors.

\begin{tabular}{|c|c|c|c|}
\hline \multicolumn{4}{|l|}{ Wald Test: } \\
\hline \multicolumn{4}{|c|}{ Equation: Untitled } \\
\hline Test Statistic & Value & $\mathrm{df}$ & Probability \\
\hline F-statistic & 40.29070 & $(4,1)$ & 0.1175 \\
\hline Chi-square & 161.1628 & 4 & 0.0000 \\
\hline \multicolumn{4}{|c|}{ Null Hypothesis: $C(7)=C(8)=C(9)=C(10)=0$} \\
\hline \multicolumn{4}{|c|}{ Null Hypothesis Summary: } \\
\hline \multicolumn{2}{|c|}{ Normalized Restriction $(=0)$} & Value & Std. Err. \\
\hline $\mathrm{C}(7)$ & & -1.194512 & 0.148777 \\
\hline $\mathrm{C}(8)$ & & 0.005923 & 0.000635 \\
\hline $\mathrm{C}(9)$ & & -0.022070 & 0.003371 \\
\hline $\mathrm{C}(10)$ & & 0.635344 & 0.082860 \\
\hline
\end{tabular}

Table 1. Bound test

Source: Pažun, 2014; 
As in this model four indicators exist, the log of the real effective exchange rate, the level of net foreign assets, the fiscal deficit and the log of real GDP per capita, the coefficient is $3(\mathrm{k}=3)$, therefore at the level of significance of 5\% interval is $(3.384 .23)$ and at the level of $1 \%$ interval is (4.30 5.23). It is concluded that the obtained F-statistic value exceeds the upper limit of the interval, which confirms the long-run relationship between real effective exchange rate (REER) and given indicators.

The next step was coefficients estimation by the least squares method (LS method).

Table 2 shows the estimated long run relationship and chosen lag structure for the ARDL modeling:

Table 2. Estimated Long Run Coefficients using the ARDL Approach

\begin{tabular}{|l|l|l|l|l|}
\hline \multicolumn{1}{|c|}{ Variable } & \multicolumn{1}{c|}{ Coefficient } & \multicolumn{1}{c|}{ Std. Error } & \multicolumn{1}{c|}{ t-Statistic } & \multicolumn{1}{c|}{ Prob } \\
\hline $\mathrm{C}$ & 0.209927 & 0.185903 & 1.12923 & 0.4614 \\
\hline $\mathrm{d}(\mathrm{NFA})$ & 0.001999 & 0.000917 & 2.179205 & 0.2739 \\
\hline $\mathrm{d}(\mathrm{FB})$ & -0.01311 & 0.002078 & -6.30951 & 0.1001 \\
\hline $\mathrm{d}(\mathrm{LGDPO})$ & 0.498811 & 0.040639 & 12.27424 & 0.0518 \\
\hline $\mathrm{d}(\mathrm{LOGOP})$ & -0.09347 & 0.035861 & -2.60632 & 0.2332 \\
\hline LR(-1) & -1.19451 & 0.148777 & -8.0289 & 0.0789 \\
\hline $\mathrm{NFA}(-1)$ & 0.005923 & 0.000635 & 9.325185 & 0.068 \\
\hline FB(-1) & -0.02207 & 0.003371 & -6.54692 & 0.0965 \\
\hline LGDPO(-1) & 0.635344 & 0.08286 & 7.66767 & 0.0826 \\
\hline
\end{tabular}

Source: Pažun, 2014;

Note: 1) lr is dependent variable, that is, real effective exchange rate, expressed in $\ln$;

2) highlighted coefficients are significant at the $10 \%$ level;

3) d - delta, difference, stationary representation of time series, their first lag;

4) ,t-1 $1^{\text {“ }}$ - related to first lag, in table expressed as LR(-1).

Table 2 shows statistical significance in the long-run of most coefficients (those highlighted).

The result in the Table 2, looking at fiscal balance, shows that higher fiscal balance, ie. lower fiscal deficit leads to an increase in national savings, thereby decreasing the equilibrium level of the exchange rate. In this case, coefficient -0.02207 by fiscal balance indicator means that one percent increase in the fiscal balance in terms of GDP (relative to selected trading partners) leads to a reduction in the equilibrium exchange rate of about $0.02 \%$ (if the other indicators do not change).

Furthermore, the result shows that the better the NFA position (relative to GDP), ,higher" is equilibrium level. The 0.006 in front of net foreign assets variable means that ten percent increase in net foreign assets leads to increasing of level that represents the equilibrium in the long term by $0.06 \%$ (if the other indicators do not change).

The model shows that there was a significant effect of real per capita income on equilibrium. One percentage increase (the logarithms of the values) of given variable results in increasing in the exchange rate equilibrium level of about $0.6 \%$ (if the other indicators do not change). 
The estimated exchange rate misalignment based on the above long-run relationship is plotted in Figure 1. The figure shows that the REER is overvalued constantly and has remained so even after 2009 depreciation, as well as after 2013.

Figure 1. ERER approach. Real effective exchange rates (REER) and estimated equilibrium real exchange rates (ERER)

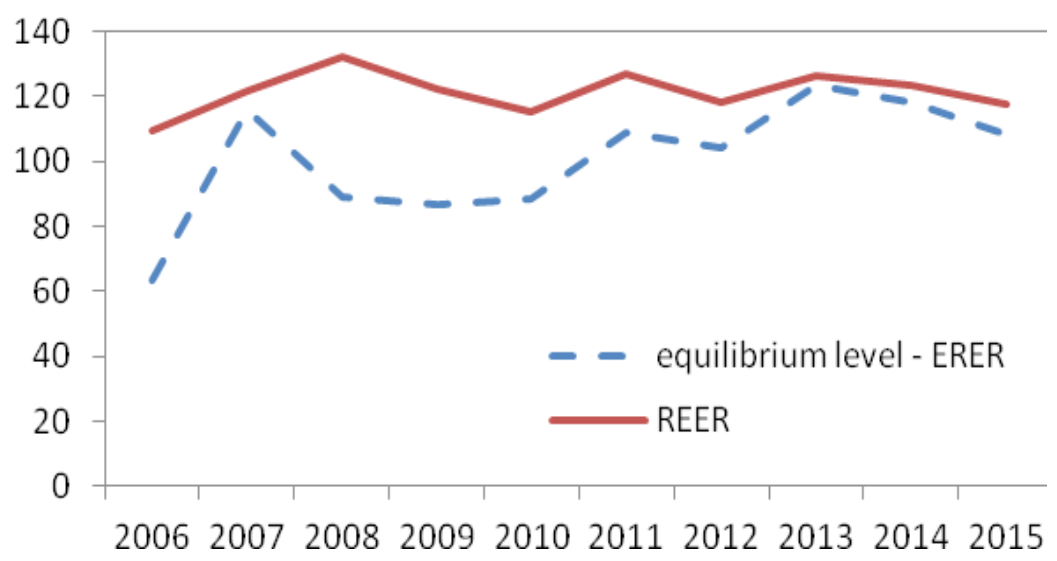

Source: Authors' calculations ERER, 2015;

Figure 2. ERER approach. Exchange rate misalignment (in percent)

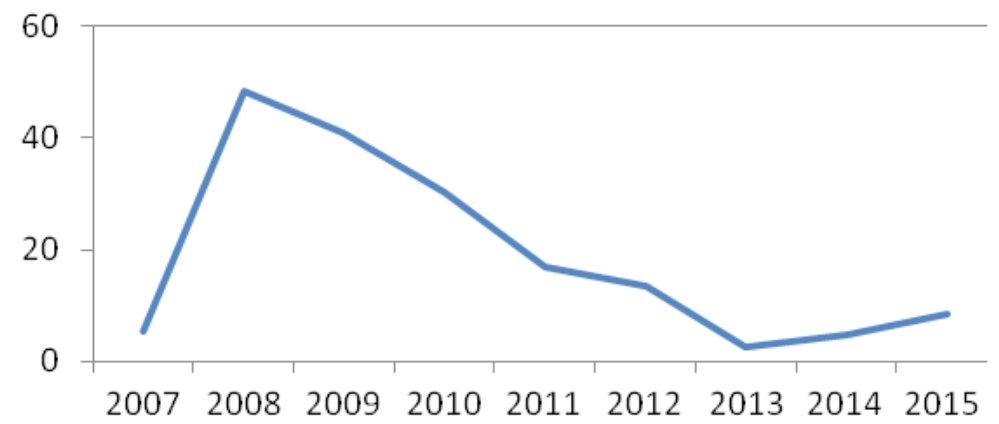

Source: Authors' calculations ERER, 2015;

Figure 1 and Figure 2 show that in 2007 REER is overvalued about 5.5\%, with increasing next year. In fact, the real effective exchange rate increases in this period from 121 to 132 dinar (according to National Bank of Serbia's data), while the estimated equilibrium decreases from 115 to 89 dinars, so the gap increases. In subsequent years, the deviation is reduced. In 2011 and 2012, the exchange rate is overvalued by about $16 \%$ and 13\%, respectively. In 2013, even single-digit deviation exists, according to research, as the closest to the estimated equilibrium, around $2.6 \%$, and in the coming year, this difference increases slightly to $4.8 \%$. Due to behavior of the effective exchange rate by October 2015, effective rate should again depreciate by $8.5 \%$ in order to remain on the equilibrium path. 


\section{Agricultural sector in Serbia}

Agriculture in Serbia is the most important part of economy and helps development of rural areas. Agriculture's contribution to Serbia's GDP remains high. In 2014, agriculture accounted for $9.1 \%$ of GDP, compared to the EU 27 average of $2 \%$. This could be explained due to Serbia's fertile land and favorable natural conditions for agricultural production, as well as delays in structural changes in other sectors. According to the Serbian Statistical Office, $21 \%$ of the total labor force in the country works in agricultural sector.

Furthermore, agriculture is one of the most important export sectors in Serbia, with approximately 65 billion dinars in 2014, about $5 \%$ higher than in 2013 . This trend increases in 2015, with almost 90 bilion dinars agro-food exports.

According to data of Statistical Office of the Republic of Serbia total agro-food imports in Serbia were valued in 2013 approximately 15 percent higher than in 2012. In 2014 agrofood imports reached approximately 43 billion RSD, or 11\% higher value than in 2013 .

The European Union remains the most important trading partner for Serbia.

Exchange rate fluctuations in 2016 will affect the agricultural markets more than ever, because there is an expectation of US dollar to strengthen, while the currencies of Latin America and Europe become weaker. During 2016 exchange rates will have a higher impact on the agricultural raw materials market more than ever, according to Dutch bank Rabobank, the leading financier of farmers and agro-companies worldwide. ${ }^{5}$

It is expected that the US dollar strengthen in 2016, and many emerging markets are likely to mitigate the monetary policy. When it comes to the individual agricultural raw materials, the Bank argues that sugar has the most optimistic prospects of all agricultural raw material for 2016. It is expected that the price of this sweetener, which is predicted that in the 4th quarter of this year reaches an average value of 14.5 cents per pound, rises to 15.5 cents in the 4th quarter in 2016.

The price of wheat is likely to be unstable because competing bid from the Black Sea region continues to displace traditional exporters.

\section{Conclusion}

This paper consists of comprehensive overview of technique developed by IMF CGER, in order to estimate the equilibrium exchange rate in country that have experienced high macroeconomic volatility and not finished structural reforms.

The paper provides estimation of specific single-country equation for the ERER approach.

The study shows that long-term relationship between the real effective exchange rate and a set of fundamental variables exists, and, therefore, dependent and independent variables should not be considered independently or individually.

5 Source: https://economics.rabobank.com/publications/ 
Any kind of "strengthening" the dinar has "artificial" character and is not a sustainable state. For example, appreciation in 2013 was not the result of better foreign trade, increasing the competitiveness of Serbia, better economic position of the country.

As the results of this study show, the dinar should be depreciated. In that exchange rate would increase exports and reduce the current account deficit. Furthermore, weakened dinar would enable more competitive domestic demand, independently of the export growth. This situation contributes in employment increasing and economic activity of the country.

The results need to be taken with caution, given the many shortcomings that restricted econometric analysis or the conclusion. Certainly, that was the reason why the IMF in the past did not provide this type of econometric research in case of Serbia. Significantly large limitation to the data exists, ie . unavailability of relevant data or relatively small sample size. In fact, the decomposition of former Yugoslavia, later Montenegro secession, as well as Kosovo and Metohija, makes availability of reliable longer time series more complicated. Finally, it has to be mentioned methodology mismatch for calculating values of specific variables.

\section{Literature}

1. Ajevskis, V., Rimgailaite, R., Rutkaste, U., Tkačevs, O. (2012): The assessment of equilibrium real exchange rate of Latvia, Working paper 4/2012, ISBN 9789984-888-11-8. Latvias Bank, (available at: https://www.macroeconomics.lv/sites /default/files/wp4-2012_assesment_of_equilibrium_2.pdf).

2. Bussière, M., Ca' Zorzi, M., Chudík, A., Dieppe, A. (2010): Methodological Advances in the Assessment of Equilibrium Exchange Rates, ECB Working Paper Series, No. 1151/2010. European Central Bank, (available at: https://www.ecb.europa.eu/pub/pdf/ scpwps/ecbwp1151.pdf).

3. Clark, P.B., MacDonald, R. (1998): Exchange Rates and Economic Fundamentals: A Methodological Comparison of BEERs and FEERs, IMF Working Paper WP/98/67, 38, (available at: https://www.imf.org/external/pubs/ft/wp/wp9867.pdf).

4. Driver, R., Westaway, P. (2004): Concepts of Equilibrium Exchange Rates, Working Paper no. 248, ISSN 1368-5562. Bank of England, (available at: http:/www. bankofengland.co.uk/archive/Documents/historicpubs/workingpapers/2004/wp248. pdf).

5. Egert, B., Halpern, L., MacDonald, R. (2006): Equilibrium Exchange Rates in Transition Economies: Taking Stock of the Issues, Journal of Economic Surveys, Vol. 20, No. 2, pp. 257-268.

6. Gujarati, D., Porter, D. (2009): Basic Econometrics, 5th edition, McGraw-Hill Education (UK) Ltd., 944 pages, ISBN: 0-07-127625-4, 978-0-07-127625-2, 0-07-714355-8, 9780-07-714355-8.

7. Hinkle, L.E., Montiel, P.J. (1999): Exchange Rate Misalignments: Concepts and 
Measurements for Developing Countries,World Bank Publication. Oxford University Press.

8. IMF (2006): Methodology for CGER Exchange Rate Assessments. [pdf] Research Department, International Monetary Fund, (available at: www.imf.org/external /pubs/ft/weo/2013/02/pdf/text.pdf).

9. IMF (2008): Republic of Serbia: Selected Issues, IMF Country Report No. 08/55. Washington, DC: IMF, pp. 30-36, (available at: https://www.imf.org/external/pubs/ $\mathrm{ft} / \mathrm{scr} / 2008 / \mathrm{cr} 0855 . \mathrm{pdf})$.

10. IMF (2013): Republic of Serbia: 2013 Article IV Consultation, IMF Country Report No. 13/20655. Washington, DC: IMF, pp. 45, (available at: https://www .imf.org/external/pubs/ft/scr/2013/cr13206.pdf).

11. IMF (2013): World Economic Outlook Database October 2015. [online] Washington, DC: IMF (available at: http://www.imf.org/external/ns/cs.aspx?id=28).

12. Lane R.P., Milesi-Ferretti G.M. (2007): The external wealth of nations mark II: Revised and extended estimates of foreign assets and liabilities, 1970-2004, Journal of International Economics 73/2007, pp. 223-250.

13. Lane R.P., Milesi-Ferretti G.M., Updated and Extended "External Wealth of Nations" Dataset, 1970-2011. (aailable at: http://www.philiplane.org/EWN.html).

14. Lane, R.P., Milesi-Ferretti, G.M. (2011): External Adjustment and the Global Crisis, IMF Working Paper WP/11/197. Washington, DC: IMF, (available at: http://papers. ssrn.com/sol3/papers.cfm?abstract_id=1917918).

15. Lee, J., Milesi-Ferretti, G.M., Ostray, J., Prati, A., Ricci, L.A. (2008): Exchange Rate Assessment: CGER Methodologies, IMF Occasional Paper No. 261/2008, Washington, DC: IMF, (available at: https://www.imf.org/external/pubs/nft /op/261/op261.pdf).

16. MacDonald, R. (2000): Concepts to Calculate Equilibrium Exchange Rates: An Overview, Discussion Paper 3/00, Economic Research Group of the Deutsche Bundesbank, (available at: https://www.bundesbank.de/Redaktion/EN/Downloads/ Publications/Discussion_Paper_1/2000/2000_07_03_dkp_03.pdf? blob=publicationFile).

17. Maslac, T. (2014): Serbia Exporter Guide, Road Map to the Serbian Market, no. of report RB1416, USA, (available at: http://gain.fas.usda.gov/Recent $\% 20$ GAIN\%20Publications/Exporter\%20Guide_Belgrade_Serbia_12-31-2014.pdf).

18. Maslac, T. (2015): Serbian Agriculture Overview and Best Prospects, no. of report RB1504, USA, (available at: http://gain.fas.usda.gov/Recent\%20GAIN\%20 Publications/Serbian\%20Agriculture\%20Overview\%20and\%20Best\%20 Prospects\%20-\%202015_Belgrade_Serbia_6-9-2015.pdf). 
19. Narodna banka Srbije, Devizni kursevi (available at: http://www.nbs.rs/internet /latinica/40/40_5/).

20. Pažun, B. (2014): Procena ravnotežnog deviznog kursa Srbije upotrebom ES metodologije MMF-a, Megatrend revija - Megatrend Review, Vol. 11, No. 2, (available at: http://scindeks-clanci.ceon.rs/data/pdf/1820-3159/2014/1820-31591402117P.pdf)

21. Pažun, B. (2014): Savremeni koncepti procene ravnotežnog realnog deviznog kursa, HiT Menadžment, God. 2(2)2014, UDK 339.743.053, ISSN 2334-8267, 106-112.

22. Pažun, B. (2014): Primena CGER metodologija za procenu ravnotežnog realnog deviznog kursa u Srbiji, Ph.D. dissertation, Faculty of international economy, Megatrend University, Belgrade, Serbia.

23. Pazun, B., Langovic Milicevic, A., Langovic, Z. (2014): Equilibrium real exchange rate modelling in Serbia - ES approach, Annals of faculty engineering Hunedoara International journal of engineering, XII/2014, Fascicule 4(November), 367-370, ISSN 1584 - 2665, (available at: http://annals.fih.upt.ro/pdf-full/2014/ANNALS-2014-4-61. pdf).

24. Pesaran, H. (2006): Estimation and Inference in Large Heterogeneous Panels with a Multifactor Error Structure, Econometrica, Volume 74, Issue 4, pages 967-1012.

25. Pesaran, M.H., Shin, Y., Smith, R.J. (2001): Bound Testing Approaches to the Analysis of Level Relationships, Journal of Applied Econometrics, J. Appl. Econ. 16: 289-326. DOI: 10.1002/jae.616.

26. Rabobank, Economic Research, (available at: https://economics.rabobank.com/ publications/).

27. Republički zavod Republike Srbije, Spoljnotrgovinska robna razmena Republike Srbije, (available at: http://webrzs.stat.gov.rs/WebSite/public/PublicationView.aspx? $\mathrm{pKey}=41 \& \mathrm{pLevel}=1 \&$ pubType=2\&pubKey=3308).

28. Ricci, L.A., Milesi-Ferretti G.M, Lee, J. (2008): Real Exchange Rates and Fundamentals: A Cross-Country Perspective, IMF WP/08/13, Washington, DC: IMF, (available at: https://www.imf.org/external/pubs/ft/wp/2008/wp0813.pdf)

29. Siregar, R., Rajan, R. (2006): Models of Equilibrium Real Exchange Rates Revisited: A Selective Review of the Literature, CIES. Discussion Paper No. 0604. University of Adelaide, Adelaide, 5005, Australia, (available at: https:// www.adelaide.edu.au/cies/documents/papers/0604.pdf)

30. Siregar R. (2011): The Concepts of Equilibrium Exchange Rate: A Survey of Literature, Munich Personal RePEc Archive. Paper No. 28987. pp. 21-37, (available at: https:// mpra.ub.uni-muenchen.de/28987/).

31. UN (2013) (database).[online] (available at: http://data.un.org/).

32. WDI (2013): World Development Indicators \& Global Development Finance. 
Washington, DC: The World Bank. (available at: http://databank.worldbank .org/ddp/home.do?Step=1\&id=4).

33. Weber, A., Yang, C. (2011): Armenia: An Assessment of the Real Exchange Rate and Competitiveness, WP/11/20, Middle East and Central Asia Department, International Monetary Fund, (available at: https://www.imf.org/external /pubs/ft/wp/2011/wp1120.pdf)

\section{APPENDIX}

Table A1. Data description for ERER approach

\begin{tabular}{|c|c|c|}
\hline VARIABLE & DESCRIPTION & SOURCE \\
\hline $\mathrm{fb}$ (fiscal balance) & $\begin{array}{l}\text { fiscal deficit/GDP, relative to trading partners; formula is: } \\
\mathrm{fb} / \mathrm{BDP}-\Sigma_{\mathrm{i}}(\mathrm{fb} / \mathrm{BDP}) ; \mathrm{w}_{\mathrm{i}} \text { are trade partner ponders }\end{array}$ & $\begin{array}{l}\text { WEO, NBS (data in } \\
\text { period 2002-2014) }\end{array}$ \\
\hline $\begin{array}{l}\operatorname{loggg}(\text { general } \\
\text { government } \\
\text { consumption) }\end{array}$ & $\begin{array}{l}\text { public spending/GDP, relative to trading partners, in ln; } \\
\text { formula is: } \\
\mathrm{gg} / \mathrm{GDP}-\mathrm{L}_{\mathrm{i}}\left(\mathrm{gg}_{\mathrm{i}} / \mathrm{GDP}_{\mathrm{i}}\right) ; \mathrm{w}_{\mathrm{i}} \text { are trade partner ponders }\end{array}$ & $\begin{array}{l}\text { WEO(data in period } \\
\text { 2002-2014) }\end{array}$ \\
\hline logti (total investment) & $\begin{array}{l}\text { gross investment/BDP, relative to trading partners, in ln; } \\
\text { formula is: } \\
\text { ti/GDP- } \mathrm{w}_{\mathrm{i}}\left(\mathrm{ti}_{\mathrm{i}} / \mathrm{GDP}_{\mathrm{i}}\right) ; \mathrm{w}_{\mathrm{i}} \text { are trade partner ponders }\end{array}$ & $\begin{array}{l}\text { WEO(data in period } \\
\text { 2002-2014) }\end{array}$ \\
\hline logop (openess) & gross exchange (import+export)/GDP; in $\ln$ & $\begin{array}{l}\text { WEO, NBS (data in } \\
\text { period 2002-2014) }\end{array}$ \\
\hline $\log t$ (terms of trade) & terms of trade; in ln & $\begin{array}{l}\text { RZS (data in period } \\
\text { 2004-2014) }\end{array}$ \\
\hline $\operatorname{lgdpO}$ & $\begin{array}{l}\text { real GDP/per capita, } \\
\text { in current prices US\$, in ln }\end{array}$ & $\begin{array}{l}\text { WEO (data in period } \\
\text { 2002-2014) }\end{array}$ \\
\hline Nfa & net foreign assets & $\begin{array}{l}\mathrm{LM}^{6}, \mathrm{NBS} \text { (data in } \\
\text { period 2002-2014) }\end{array}$ \\
\hline $\mathrm{Lr}$ & real effective exchange rate, in $\ln$ & $\begin{array}{l}\text { NBS (data in period } \\
\left.2002-2015^{7}\right)\end{array}$ \\
\hline
\end{tabular}

Note: access to databases IMF WEO, NBS, RZS in June 2015;

6 Lane \& Milesi-Ferreti database

7 data until October 2015 


\title{
EKONOMETRIJSKA ANALIZA DEVIZNOG KURSA U SRBIJI I UTICAJ NA POLJOPRIVREDNI SEKTOR
}

\author{
Brankica Pažun ${ }^{8}$, Zlatko Langović ${ }^{9}$ Ana Langović Milićevićc ${ }^{10}$
}

\begin{abstract}
Rezime
Ovaj rad pokušava empirijski da oceni ravnotežni nivo deviznog kursa. U tu svrhu se koristi redukovana forma pristupa ravnotežnog realnog deviznog kursa (ERER), razvijena od strane MMF konsultativne grupe za pitanja deviznog kursa (CGER).

U sprevedenoj single-country analizi koristio se ARDL pristup. Pošlo se od dinamičkog modela kojim se predstavio realni efektivni devizni kurs, odnosno redukovana relacija između zavisne realnog efektivnog deviznog kursa i skupa fundamentalnih promenljivih. Kako bi se utvrdilo postojanje dugoročne veze između promenljivih, koristio se granični test (bound test). Koristila se F - statistika za testiranje dugoročne relacije između realnog efektivnog deviznog kursa i samih fundamenata. Obzirom da su bile ispunjene odgovarajuće pretpostavke, sprovedena je ocena koeficijenata metodom najmanjih kvadrata. Rezultati su pokazali konstantnu precenjenost dinara na srednji rok.
\end{abstract}

Ključne reči: ARDL, prilagođavanje, ravnotežni realni devizni kurs, ERER, Srbija

JEL: $C 33, F 31, F 41, O 24, Q 10$

8 Docent, dr Brankica Pažun, Alfa univerzitet, Fakultet za inženjerski menadžment, Bul. vojvode Mišića 43, 11000 Beograd, Srbija, Tel: +381 114140 420, e-mail: bpazun@gmail.com

9 Vanredni profesor, dr Zlatko Langović, Univerzitet John Naisbitt, Fakultet za poslovne studije, Goce Delčeva 8, 11070 Beograd, Srbija, Tel: +381 1122030 29, e-mail: zlmegatrend@gmail.com

10 Redovni profesor, dr Ana Langović-Milićević, Univerzitet u Kragujevcu, Fakultet za hotelijerstvo i turizam, Vojvođanska bb, 36210 Vrnjačka Banja, Srbija, Tel: + 38136515 0024, e-mail: ana.langovic@,kg.ac.rs

EP 2016 (63) 1 (47-59) 